УДК: 378.147

DOI:

Максим Імерідзе, кандидат педагогічних наук, докторант Національного університету “Чернігівський колегіум” імені Т.Г. Шевченка

Іван Биков, директор ПП ЗОШ “Майбуття" I-III ступенів

Дмитро Величко, викладач кафедри образотворчого мистеитва,

ДЗ “Південноукраӥнський національний педагогічний університет імені К.Д. Уиинського”

\title{
ВИКОРИСТАННЯ ГЕЙМІФІКАЦЇ̈ В ОСВІТНЬОМУ СЕРЕДОВИЩІ ЗАКЛАДІВ ВИЩОЇ ОСВІТИ
}

Стаття присвячена новачіям в процесі професійного становлення студентів бакалаврату різних спеціальностей. Поширення комп'ютерних ігор дозволяе створити нові освітні практики. Використання гейміфікації освітнього процесу у вищій школі стає необхідною освітньою практикою, щуо пропонує нові форми освіти та професійної підготовки. Гейміфікація - застосування елементів гри та ігрових принципів у неігрових контекстах для досягнення реальних освітніх иілей під час вивчення освітнього предмету.

Мета статті - проаналізувати процес гейміфікаиії в освітньому середовищі закладів вищої освіти в професійному становленні студентів бакалаврату різних спеціальностей.

Наукова новизна полягає у визначенні основних напрямів використання гейміфікації як освітньоі практики в закладах вищої освіти.

Ключові слова: професійне становлення студентів; гейміфікація; освітній процес; заклади вищоі освіти.

Jim. 15.

Maksym Imeridze, Ph.D. (Pedagogy), Doctoral Student, Taras Shevchenko National University "Chernihiv Colehium"

Ivan Bykov, Director of the Secondary School "Futureo of the I-III levels

Dmytro Velychko, Lecturer of the Fine Arts Department, Faculty of Arts and Graphics, State Institution

“Kostyantyn Ushynskiy South Ukrainian National Pedagogical University'

\section{USE OF GAMIFICATION IN THE EDUCATIONAL ENVIRONMENT OF HIGHER EDUCATION INSTITUTIONS}

The article is devoted to innovations in the process of professional development of undergraduate students of various specialties. The proliferation of computer games has created new educational practices. The use of gamification of the educational process in higher education is becoming a necessary educational practice that offers new forms of education and training. Visualization activates cognitive activity and facilitates the assimilation of educational material by undergraduate students of various specialties. Gamification - the application of elements of the game and game principles into non-game contexts, introduced in modern online games, to motivate students and achieve real educational goals while studying the subject.

The purpose of the article is to analyze the process of gamification in the educational environment of higher education institutions in the professional development of undergraduate students of various specialties.

Methodology. A descriptive method with elements of comparative analysis, a method of modeling that contributed to a comprehensive study of the problem.

Scientific novelty is to determine the main areas of use of gamification as an educational practice in higher education institutions.

Conclusions. 1. In the process of teaching undergraduate students, the use of gamification allows to expand the possibilities of traditional higher education and shift the emphasis to interactive learning. This will allow students to think outside the box and develop self-control, as well as diversify the format of educational activities. 2. An indicator of professional development is professionalism. In this process, gamification becomes a necessary educational practice that offers new forms of education and training. Visualization and simultaneous influence on different senses intensify cognitive activity and facilitate the assimilation of undergraduate students of different specialties of educational material. 3. To actively use the gamified education system, it is necessary to study the theoretical materials, try to gamify a particular topic or lesson and analyze how undergraduate students react to such an innovation. 
The use of computer games in the educational process of higher education institutions promotes the development of personality, communication skills, improves the professional development of students.

Keywords: professional development of students; gamification; an educational process; institutions of higher education.

П

остановка проблеми. Основним завданням розвитку вищої освіти в Україні $\epsilon$ створення умов для професійного становлення майбутніх фахівців. Професійне становлення особистості Л. Шнейдер визначає, як “формування професійної спрямованості, компетентності, соціально значущих і професійно важливих якостей і їхньої інтеграції, готовність до постійного особистісного і професійного зростання" [5, 99; 11, 122]. Професійне становлення майбутнього фахівця залежить від певних характеристик людини, які визначають кінцевий успіх формування студента як професіонала та його готовність до професійної діяльності. На тлі розвитку Інтернету та широкого поширення комп'ютерних ігор виникла необхідність створення нових привабливих освітніх практик, зокрема, гейміфікації як інноваційної форми навчання і професійної підготовки зі значним потенціалом щодо доповнення $\mathrm{i}$ розширення можливостей традиційного навчання.

Гейміфікацію визначають як застосування елементів гри та ігрових принципів у неігрових контекстах [13], впровадження елементів гри у практику в повсякденному житті, ніяк не пов'язаному з іграми [9], використання ігрових правил, “запроваджених у сучасних онлайн-іграх, для мотивації тих, хто навчається, і досягнення реальних освітніх цілей під час вивчення освітнього предмета" [10].

Невирішеними раніше частинами проблеми вважаємо відмінність гейміфікації від інших освітніх технологій. Ці освітні технології засновані на принципах ігри та в них застосовуються підходи, характерні для комп'ютерних ігор, з метою підвищення залучення тих, хто навчається, до процесу навчання, щоб розв'язувати прикладні завдання [9].

Актуальність проблеми. Так, надумкуВ. Бодрова, до характеристик, що значно покращують результати освітнього процесу у вишах, можна віднести: професійну мотивацію як спонукальну та спрямовуючу активність особистості для задоволення не тільки біологічних потреб, але й у праці, спілкуванні, самоствердженні, самореалізації та самовдосконаленні; загальну і професійну підготовленість у формі попередніх і кваліфікаційних знань, умінь та навичок, які необхідні для виконання стандартних та нетипових професійних завдань; рівень професійної готовності та резервів організму до трудової діяльності, розвиток професійно важливих фізіологічних функцій аналізаторів та таких фізичних якостей, як сила, витривалість та швидкість; стан індивідуально-психологічних функцій людини, що характеризують пізнавальні процеси $[1 ; 5,100]$.

Відомо, що сучасні студенти вишів живуть в особливому інтерактивно-ігровому просторі, тому гейміфікація власне і використовується для створення звичного й затишного для них середовища. Це середовище при правильній організації освітнього процесу сприяє підвищенню ефективності навчання.

Аналіз останніх досліджень та публікацій. Сучасним підходам до розуміння поняття “гейміфікації” в освіті присвячено роботи вітчизняних дослідників: В. Биховця, О. Кочкурової, Є. Новікової, О. Пасічник, Н. Саєнко, [5; 7; 8]. В дослідженнях зарубіжних науковців (К. Вербаха, П. Новоструєва, П. Храмкіна, А. Marczewski та ін.) також визначено різні аспекти гейміфікації як освітньої технології [2; 6; 10; 13].

Мета статті - проаналізувати процес гейміфікації освітнього середовища закладів вищої освіти в професійному становленні студентів бакалаврату різних спеціальностей.

Виклад основного матеріалу. Натепер вже накопичено значний досвід застосування ігор в освіті: як в оффлайн-, так і онлайн-режимах, як в електронному так і в дистанційному варіантах. Однак все ще не існує систематизованого підходу до вивчення гейміфікації, що дозволяє використовувати переваги цієі технології в умовах ЗВО повною мірою.

Це необхідно для покращення результатів освітнього процесу, що особливо важливим є для студентів бакалаврату. Саме в період освітнього процесу в бакалавраті активно починається професійне становище особистості студентів. У своїх дослідженнях Е. Зеєр [3,6] виділяє “три етапи професійного становлення особистості: адаптація, інтенсифікація та ідентифікація. На початковому етапі навчання важливими є такі якості: прагнення до саморозвитку, високий рівень працездатності, дисциплінованість, сумлінність та відповідальність. Усе це пов'язано з тим, що студенти на цьому етапі професійного становлення адаптуються до умов та змісту освітнього процесу, визначаються нові соціальні ролі, взаємостосунки 3 викладачами та 3 
одногрупниками. На наступному етапі професійного становлення провідною стає науково-пізнавальна діяльність. Це етап інтенсифікації, який передбачає розвиток загальних та спеціальних здібностей, інтелекту, відповідальності за своє становлення та самостійності”. Наукові дослідження О. Кочкурової також підтверджують важливість процесу розвитку спеціальних здібностей студентів вишів $[5,100]$. Поняття “гейміфікація” було уведено розробником комп'ютерних ігор Н. Пеллінгом [15] у 2002 p.

Комп'ютерні та відеоігри, що лежать в основі гейміфікації, відрізняються від інших популярних медіа. Вони інтерактивні й дозволяють гравцям виступати в різних ролях (ученого, мандрівника, винахідника, політичного лідера та ін.), ставити завдання, здійснювати вибір та оцінювати його наслідки [7]. Гравців в іграх називають геймерами. Вони мають свободу вибору та здатні впливати на ситуацію як у віртуальному, так і в реальному середовищі.

Зауважимо, що провідні світові “компанії почали стрімко впроваджувати гейміфікацію у свої ділові процеси" $[8,188]$.

Розробники ігрових моделей і додатків, призначених для використання у сфері освіти, називають “кілька функцій гри в сучасному освітньому процесі” [14], а саме: “гра як спосіб створення інноваційного середовища; гра як спосіб отримання знань із різних галузей; гра як симуляція; гра як спосіб дискутування; гра як виконання досліджень; гра як оволодіння практичними навичками; гра як спосіб рольової поведінки і рефлексіі'.

Розкриємо основні складові гейміфікації. Зарубіжний дослідник К. Капп подає більш розгорнуте визначення “гейміфікації як використання принципів ігрової механіки, естетики й мислення для того, щоб залучити тих, хто навчається, до освітнього процесу, підвищити їхню мотивацію, активізувати навчання й вирішити проблеми" $[12,232]$. Він зосереджує увагу на потребі отримання балів, бонусів, просуванні на наступний рівень. Вважає це “фундаментом усього процесу гейміфікаціі”. Зарубіжні дослідники вважають, що ігрове мислення $є$ найважливішим елементом гейміфікації. А також доводять, що “ключовим моментом гейміфікації $є$ залучення учасників до процесу освітньої гри” [2; 13].

Натепер вважається, що розробники освітніх комп'ютерних ігор мають враховувати такі пункти: “гра повинна бути кольоровою, динамічною, мати цікаву сюжетну лінію; у грі повинні бути представлені як освітні матеріали в різних формах (текст, відео, графіка, анімація), так і різноманітні форми контролю знань (тести із закритою та відкритою формами відповіді, порівняння, установлення взаємозв'язку, співвідношень); гра повинна мати ієрархічну структуру, тобто складатися з кількох залежних між собою рівнів; результати контролю знань повинні фіксуватися і враховуватися під час гри; у грі повинна бути надана можливість отримання додаткової інформації для подальшого стимулювання проходження гри" $[8,189]$.

Визначимо специфічні риси гейміфікації: компоненти, динаміку, механіку.

Проаналізуємо спочатку компоненти згідно з дослідженням К. Вербаха, Д. Хантера: “це більш конкретна форма, яку приймають механіка й динаміка". Найважливіші ігрові компоненти: досягнення (певних цілей); аватари (візуалізація характеру гравця); бейджи (візуалізація досягнень); битви з босами (особливо складні випробування для переходу на наступний рівень); колекціонування (накопичення наборів предметів або бейджів); битви (конкретний раунд боротьби, зазвичай дуже динамічний); доступ до контенту (подальший зміст гри після того, як гравці досягають певних показників); подарунки (можливість ділитися ресурсами з іншими); рейтинги лідерів (візуалізація розвитку й досягнень гравця); рівні (певні кроки щодо розвитку гравця); очки (кількісне відображення розвитку гри); квести (конкретні завдання з власними цілями й винагородами); соціальний профіль (візуалізація гри в соціальній мережі гравця); команди (певні групи гравців, які працюють разом заради спільної мети); віртуальні товари (ігрові активи 3 суб'єктивною або реальною грошовою цінністю) $[2,28]$.

Згідно П. Новоструєва, “динаміка - це високий рівень абстракції. Найважливішими ігровими динаміками є емоції (допитливість, дух суперництва, розчарування, відчуття щастя), розповідь (послідовна, безперервна сюжетна лінія), просування (зростання гравця і його розвиток), відносини (соціальні взаємодії формують почуття товариськості, відчуття власного статусу, альтруїзму)" [6, 74].

Науковець П. Новоструєв також стверджує, що “механіка освітньої гри - це основні процеси, які рухають діями гравця й забезпечують його залучення до гри. Типовими ігровими механіками $\epsilon$ такі: завдання (загадки або будь-які інші завдання, які вимагають зусиль для їхнього вирішення); шанс (елементи випадковості); змагання (група гравців або один гравець 
перемагають, а інша група або інший гравець програють); співробітництво (гравці повинні працювати разом для досягнення спільної мети); зворотний зв'язок (інформація щодо просування гравця); накопичення ресурсів (отримання корисних або колекційних предметів); винагороди (нагороди за певні дії та досягнення); угоди (торгові операції між гравцями, безпосередньо або через посередників); ходи (почергова участь гравців); досягнення перемоги (показники, завдяки яким гравець або команда стають переможцями)" $[6,74]$.

Більшість вітчизняних та зарубіжних науковців вважають, що при розробці освітніх ігор також необхідно враховувати те, що невід'ємною частиною безлічі відеоігор є організація роботи за принципом “завдання в завданні”, тобто більші за обсягом завдання містять малозначні завдання. Це означає, що довгострокова мета розбита на середньострокові завдання (рівень 1 , $2,3)$. Більшість науковців як вітчизняних так й зарубіжних констатують, що такий підхід $\epsilon$ надзвичайно ефективним не лише у світі ігор, але й у освітній діяльності, і саме тому він був перенесений в освітній процес.

В своїх працях П. Невоструєв виділяє в гейміфікації тріаду основних елементів: “1) очки (points), що показують прогрес проходження через ігровий простір; як правило, видаються за певні дії; 2) бейджи (badges), які більшою мірою $\epsilon$ приємним доповненням, проте необхідно враховувати, що бейджи можуть видаватися як за високі результати, так і за низькі; 3) дошки лідерів (leaderboards), що відображають прогрес гравця щодо інших в ігровому просторі (levels)” $[6,73]$.

Варто наголосити на тому, що впровадження гейміфікації в процес вищої освіти неможливе без ведення акаунтів, тобто своєрідних “особистих справо студентів, у яких фіксуються всі їхні досягнення. Акаунти необхідні для послідовного відстежування прогресу гравців. Сам термін “гейміфікація" можна асоціювати з електронними чи відеоіграми, але це не є ключовою умовою процесу. Навіть за відсутності необхідного обладнання можна гейміфікувати освітній процес різних дисциплін в бакалавраті. Проте це потребує ретельної підготовки з боку викладачів цих дисциплін: важливо визначити мету, на яку спрямована діяльність студентів; досягнення цієї мети необхідно поділити на етапи, які можна відстежувати; наступний етап полягає в процесі проєктування та розробки самої гри, на кшталт настільної з графічним представлення кожного 3 рівнів; студенти мають змогу присвоїти собі імена, чи обрати аватарку; для викладача необхідно продумати систему бонусів та винагород за правильне вчасне, або додаткове виконання тих чи інших завдань; групова участь у процесі гейміфікації має сприяти підтримці загальної ігрової атмосфери $[9,346]$.

Важливо пам'ятати, що до участі в гейміфікованому освітньому процесі студенти вишів забезпечуються інструкціями (гайдами), в яких указано вимоги до поведінки під час заняття, специфіку отримання очок, особливості переходу на наступні рівні.

Модифікуючи статтю О. Карабіна, маємо зазначити, що також важливо аналізувати й результати гейміфікації $[4,45]:$ 1. Сприяє мотивації студентів бакалаврату до освітнього процесу. 2. Розвиває у студентів, особливо 1-2 курсів бакалаврату, розумові навички, просторову уяву та реакцію. 3. Заохочує до роботи в інтерактивному середовищі. 4. Формує практичні вміння та навички роботи у групах із закріпленням освітнього матеріалу. 5. Сприяе організації самостійної роботи студентів. Більшість дослідників як в Україні, так й за рубежем стверджують, що існують й недоліки впровадження гейміфікації в освітній процес вищої школи. Зокрема: нерозуміння цілей і завдань освітнього процесу; невміння впроваджувати ігрові механіки; наявність дефіциту в комунікації під час освітнього процесу; удосконалення підготовки викладачів вищої школи з використання інформаційних технологій та засобів. Також можемо констатувати, що гейміфікація робить освітній процес у вищій школі захоплюючим і цікавим, розвиває творчі здібності студентів бакалаврату різних спеціальностей $[4,45]$.

Висновки. 1. У процесі навчання студентів вишів в бакалавраті процес гейміфікації дозволяє розширити можливості традиційної вищої освіти та перенести акцент на інтерактивне навчання. Це дозволить студентам мислити нестандартно й розвивати самоконтроль, а також урізноманітнити формат освітніх занять. 2. Показником професійного становлення $\epsilon$ професіоналізм. В цьому процесі гейміфікація стає необхідною освітньою практикою, що пропонує нові форми освіти та професійної підготовки. Візуалізація й одночасний вплив на різні органи чуття активізують пізнавальну діяльність і сприяють полегшенню засвоєння студентами бакалаврату різних спеціальностей освітнього матеріалу. 3. Для активного використання гейміфікованої системи освіти, необхідно проаналізувати, як студенти бакалаврату реагують на подібне нововведення.

Використання комп'ютерних ігор в освітньому 
процесі закладів вищої освіти сприяють розвитку особистості, комунікативних умінь та навичок, покращують професійне становлення студентів.

Перспективами подальших наукових розвідок вважаємо аналіз помилок в процесі впровадження ігрових технологій в освітньому процесі ЗВО.

\section{ЛІТЕРАТУРА}

1. Бодров В. А. Психология профессиональной пригодности: учебное пособие для вузов. Москва: ПЕР CЭ, $2001.511 \mathrm{c}$.

2. Вербах К., Хантер Д. Вовлекай и властвуй. Игровое мышление на службе бизнеса. Москва, 2015. 107 с.

3. Зеер Э. Ф. Кризисы профессионального становления личности. Психологический журнал. 1997. № 6. С. 35-44.

4. Карабін О. Й. Гейміфікація в освітньому процесі як засіб розвитку молодших школярів. Педагогіка формування творчої особистості у вищій $i$ загальноосвітній школах. 2019. № 67. Т. 1. С. 44-47.

5. Кочкурова О. В. Особливості професійного становлення фахівців в умовах навчання у закладах вищої освіти. Дослідження різних напрямків розвитку психологї та педагогіки: Збірник наукових робіт учасників міжнародної науково-практичної конференції (19-20 червня 2020 р., м. Одеса). Одеса: ГО “Південна фундація педагогіки", 2020. С. 99-100.

6. Невоструев П. Ю. Применение концепции игрофикации в рамках разработки контент-стратегии. Евразийское научное объединение. 2015. T. 1. № 3 (3). C. 73-74.

7. Пасічник О. Гейміфікація процесу навчання іноземної мови студентів закладів вищої освіти. Збірник наукових пращь. Вип. 24 (1-2018). Ч. 2. С. 344-349.

8. Саєнко Н. В., Новікова Є. Б. Потенціал гейміфікації як сучасної освітньої технології в умовах ЗВО. Вісник Національного університету "Чернігівський колегіум” імені Т.Г. Шевченка. Вип. 5 (161). Серія: Педагогічні науки. Чернігів: НУЧК, 2019. С. 187-191.

9. Современные проблемы науки и образования. URL: https://www.science-education.ru/ru/article/ view?id=22236 (дата звернення: 16.07.2020).

10. Храмкин П. В. Геймифицируй это: как урок превратить в игру. URL: https:// www.ispring.ru/ eleaming- insights/gameschool/ (дата звернення: 16.07.2020).

11. Шнейдер Л. Б. Профессиональная идентичность: теория, эксперимент, тренинг. Москва: Издательство Московского психолого-социального института; Воронеж: Издательство НПО “МОДЭК”, 2004. 600 с.

12. Карр К. M. The gamification of learning and instruction: game-based methods and strategies for training and education. John Wiley \& Sons, 2012.336 p.

13. Marczewski A. Gamification: a simple introduction. New York, 2013. 288 p.

14. Moving Learning Games Forward. URL: www.educational.mit.edu/papers/movingleaminggamesforward_edarcade.pdf(дата звернення: 16.07.2020).
15. Pelling's Nick. Home Page. URL: http:// www.nickpelling.com/ (дата звернення: 16.07.2020).

\section{REFERENCES}

1. Bodrov, V. A. (2001). Psihologija professionalnoj prigodnosti: [Fitness psychology]: uchebnoe posobie dlja vuzov [textbook for universities]. Moscov, 511 p. [in Russian].

2. Verbah, K., \& Hanter, D. (2015). Vovlekaj i vlastvuj. Igrovoe myshlenie na sluzhbe biznesa [Involve and Conquer. Game Thinking at the Service of Business]. Moscow, 107 p. [in Russian].

3. Zeer, Je. F. (1997). Krizisy professionalnogo stanovlenija lichnosti [Crises of professional development of personality]. Psychological journal. No 6. pp.35-44. [in Russian].

4. Karabin, O. J. (2019). Ghejmifikacija v osvitnjomu procesi jak zasib rozvytku molodshykh shkoljariv [Gamification in the educational process as a means of developing primary school children]. Pedagogy of formation of creative personality in higher and general education schools. No 67. Vol. 1, pp.44-47. [in Ukrainian].

5. Kochkurova, O. V. (2020). Osoblyvosti profesijnogho stanovlennja fakhivciv v umovakh navchannja u zakladakh vyshhoji osvity [Features of professional development of specialists in the conditions of study in higher education institutions]. Research of different directions of development of psychology and pedagogy: Collection of scientific works of participants of the international scientific and practical conference (June 19-20, 2020, Odessa). Odesa, pp. 99-100. [in Ukrainian].

6. Nevostruev, P. Yu. (2015). Primenenie koncepcii igrofikacii $\mathrm{v}$ ramkah razrabotki kontent-strategii [Application of the Concept of Gamification as Part of Developing a Content Strategy]. Eurasian Scientific Association. Vol. 1. No. 3 (3), pp.73-74. [in Russian].

7. Pasichnyk, O. (2018). Ghejmifikacija procesu navchannja inozemnoji movy studentiv zakladiv vyshhoji osvity [Gamification of the process of learning a foreign language by students of higher education institutions]. Collection of scientific works. Vol. 24 (1), part. 2, pp.344349. [in Ukrainian].

8. Saenko, N. V. \& Novikova, Je. B. (2019). Potencial ghejmifikaciji jak suchasnoji osvitnjoji tekhnologhiji vumovakh ZVO. [The potential of gamification as a modern educational technology in the conditions of free economic education]. Bulletin of the Taras Shevchenko National University "Chernihiv Collegium”. Vol. 5 (161). Serija: Pedaghoghichni nauky. Chernighiv, pp.187-191. [in Ukrainian].

9. Sovremennye problemy nauki i obrazovaniya [Modem Problems of Science and Education]. Available at: https://www.science-education.ru/ru/article/ view?id=22236. (Accssed 16 July 2020) [in Russian].

10. Hramkin, P. V. Gejmificiruj eto: kak urok prevratitv igru [Gamify This: How to Turn a Lesson into a Game]. Available at: https:// www.ispring.ru/eleaming-insights/ gameschool/.(Accssed 16 July 2020) [in Russian].

11. Shneyder, L. B. (2004). Professionalnaya identichnost: teoriya, eksperiment, trening [Professional 
identity: theory, experiment, training]. Moscov; Voronezh. 600 p. [in Russian].

12. Kapp, K. M. (2012). The gamification of learning and instruction: game-based methods and strategies for training and education. John Wiley \& Sons. [in English].

13. Marczewski, A. (2013). Gamification: a simple introduction. New York. [in English].
14. Moving Learning Games Forward. Available at: www.educational.mit.edu/papers/movingleaminggamesforward_edarcade.pdf. (Accssed 16 July 2020) [in English].

15. Pelling's, Nick. Home Page. Available at: $\underline{\mathrm{http}: / /}$ www.nickpelling.com/.(Accssed 16 July 2020) [in English].

Стаття надійшла до редакції 17.06.2020

УДК 378.4.09

DOI:

Теодор Лещак, кандидат педагогічних наук, доиент кафедри загальної педагогіки та педагогіки вищої школи Львівського національного університету імені Івана Франка

Марія Лепех, магістр освіти, Львівського національного університету імені Івана Франка

\section{ЗМІСТ ТЕОЛОГІЧНОЇ ОСВІТИ У ЛЬВІВСЬКОМУ УНІВЕРСИТЕТІ \\ ТА ЗАГАЛЬНОЕВРОПЕЙСЬКИЙ КОНТЕКСТ (Кін. ХVIII - ПОЧ. ХХ СТ.)}

У статті розглядаються методологічні та змістові аспекти богословської підготовки студентів Львівського університету ХVIII - поч. ХХ ст. як складової австрійської вищої теологічної освіти. На підставі сучасної типології проаналізовано особливості тогочасної європейської теологічної освіти. До наукового обігу впроваджено нові джерельні матеріали, а саме - навчальні плани теологічного факультету Львівського університету вказаного періоду. Визначено перелік навчальних дисииплін, щุо їх вивчали студенти теологічного факультету Львівського університету упродовж XIX - початку XX ст., а також прослідковано динаміку змін академічних годин, виділених на їхнє вивчення. Опираючись на иі дослідження доведено, щзо зміст теологічної освіти у Львівському університеті був типовим для університетів Австрійської (АвстроУгорської) монархії. На основі досліджених архівних даних, міністерських документів $і$ проведеноі порівняльної характеристики з'ясовано позицію богословської освіти у Львівському університеті в типології тогочасної європейської вищої теологічної освіти.

Ключові слова: теологічна освіта; вища освіта; Львівський університет; Австрійська монархія; типологія.

Jim. 17.

Teodor Leshchak, Ph.D.(Pedagogy), Associate Professor of the General Pedagogy and Pedagogy of High School Department Lviv Ivan Franko National University Mariya Lepekh, Master of Education Lviv Ivan Franko National University

\section{CONTENT OF THEOLOGICAL EDUCATION IN THE UNIVERSITY OF LVIV AND THE GENERAL EUROPEAN CONTEXT (the end of XVIII-th - beginning of XX-th century)}

The article deals with the content of theological preparation of students of Lviv University of XVIII-thbeginning of the XX-th century as an element of Austrian higher theological education. Based on modern typology, the peculiarities of European theological education are analyzed from the retrospective. New research materials has been introduced to the scientific circulation, namely the curricula of the Theological Faculty of Lviv University of the specified period.

It has been found out on the basis of the theoretical literature that there were two models - the Athens and Berlin ones in European higher theological education in the XX-th century according to David Kelsi. That is the transmission of spiritual experience and rational comprehension of theological knowledge. Robert Banks adds two more models to them - the Jerusalem and Genevian, which provided for the training of missionaries and parish priests respectively.

It was operated a four-year program of theological education in the Austrian higher schools. Information on the content of higher theological education is contained in the published annual curricula of universities. It is established that during the XIX-th century, grammar of ancient Hebrew, ancient Syriac, Chaldean, Greek and Latin, church history, biblical archeology, biblical calculus, church history, didactics and catechetics, dogmatics, patriarchy, patriarchy, biblical hermeneutics, church law, moral and pastoral theology, liturgy, homiletics were studied at the Theological Faculty of Lviv University. The number of academic hours allocated to practical training has grown over the years. 